\title{
Implications of the Tax Reform Act of 2017 on Sexual Harassment in the Workplace
}

\author{
Denis Boudreau \\ University of Louisiana at Lafayette \\ S. P. Uma Rao \\ University of Louisiana at Lafayette \\ Deergha Raj Adhikari \\ University of Louisiana at Lafayette
}

The Tax Reform Act of 2017 has a limiting provision that disallows a Corporation from expensing costs related to the settlement of a sexual harassment or sexual abuse matter. If a nondisclosure agreement (NDA) is executed between the parties, the Corporation loses the right to deduct the settlement for income tax purposes. This provision has significant economic implications. The Corporation must decide if preventing the party from publicly discussing the matter and settlement is worth the cost of losing the deduction. The scientific approach to address this decision is two pronged. On one hand, such a choice can be analyzed in a capital budgeting or cost-benefit methodology and should be structured as a SWOT matrix. On the other hand, the decision relates to a binary choice of using or not executing a NDA. This decision can be modeled using a dichotomous decision function, such as, logit, probit, or a tobit model. This paper presents a historical review of laws covering sexual harassment in the workplace and how corporations should address the NDA decision.

Keywords:Sexual Harassment, Non-disclosure Agreement, Capital Budgeting, Cost-benefit Methodology, Dichotomous Decision Function

\section{INTRODUCTION}

Sexual harassment and abuse in the workplace has recently been identified as an important social issue and is receiving attention from academics, government entities and businesses. Scholars are studying the phenomena to identify cause and effect, legislators are passing regulations and laws to discourage and punish this harmful behavior and businesses are instituting policies and programs to reduce liability exposure and encourage a better work environment. The U.S. Equal Opportunity Employment Commission (EEOC) defines workplace sexual harassment as unwelcome sexual advances, requests for sexual favors, and other verbal or physical conduct of a sexual nature constitute sexual harassment when this conduct explicitly or implicitly affects an individual's employment, unreasonably interferes with an individual's work performance, or creates an intimidating, hostile, or offensive work 
environment. The EEOC states, sexual harassment is a form of sex discrimination that violates Title VII of the Civil Rights Act of 1964. Title VII applies to employers with 15 or more employees, including state and local governments. It also applies to employment agencies and to labor organizations, as well as to the federal government (The U.S. Equal Opportunity Employment Commission, "Facts About Sexual Harassment"). Sexual harassment includes persistent offensive sexual jokes, inappropriate touching, posting of offensive material, demanding sex for employment and other unwanted sexual conduct. Sexual harassment in the workplace is considered a serious problem in the U.S. and has a high cost to the economy. This offensive and illegal behavior lowers productivity, costs businesses many millions in fines and settlements and causes pain and suffering to the harassed. This study presents a historical review of sexual harassment legislation, reviews some very well-known instants of sexual harassment and discusses the implications of the recent enactment of 26 U.S. Code $\S 162$ (q).

\section{History}

Sexual harassment in the workplace most likely became widespread during WW II when many women entered the labor market and worked side by side with men. Women rarely spoke openly about the inappropriate behavior and when they did, the charges were dismissed as it being harmless or the woman's own fault. This started to change in the mid 70's. Barnes v. Train (1974) is widely recognized as the first sexual harassment case in the United States although the term sexual harassment was not used. Ms. Barnes alleged her job with the Environmental Protection Agency was eliminated because she refused to have sex with her supervisor. The district court granted the defendant's motion of summary judgement ruling that the defendant's conduct was not prohibited by Title VII. On appeal, Ms. Barnes was awarded back pay of $\$ 18,000$, a lost promotion and full-reinstatement (Barnes v. Costle,1977).

In 1975, a Cornell University employee named Carmita Wood filed for unemployment benefits (Campbell, 2016). Ms. Wood claimed she quit her job because of her manager's unwanted physical and verbal sexual advances. She was denied unemployment benefits. In her appeal to the Department of Labor, Ms. Wood told the board of her manager's offensive behavior, but her claim was rejected again. Ms. Wood approached the Human Affairs Department at Cornell for help. A small group of women heard her story and decided they would act but needed a term to describe what she and similar women have experienced. They decided to name this aggressive sexual behavior "sexual harassment." The women formed an organization to draw public attention to this poor behavior and called the group Working Women United. The group held rallies and published Ms. Wood's story. The term sexual harassment became a popular phrase and sexual harassment at work became identified as a form of illegal sex-based discrimination.

In a 1975 case, "quid pro quo sexual harassment" was recognized as a form of sex or gender-based discrimination (Williams $\mathrm{v}$ Saxbe 1975). The court found that sexual advances by a male supervisor on a female employee was an artificial barrier in the workplace and to her employment. The court refer to civil protections under Title VII of the Civil Rights Act of 1964 that prohibits employment discrimination based on race, sex, color, national origin or religion.

By the 1980's, court rulings confirmed that a woman could sue her employer for harassment under Title VII of the 1964 Civil Rights Act, using the EEOC as the vehicle for redress. The Equal Employment Opportunity Commission in 1980, defined sexual harassment, declared it as a form of discrimination under the Civil Rights Act of 1964 and established procedures and regulations. The Supreme Court in 1986, (Menitor Savings Bank v. Vinson), ruled that sexual harassment was a violation of Title VII. This important decision proclaimed standards for evaluating the conduct as not welcomed and define levels of liability for employers. Additionally, the court found speech or conduct in itself was sufficient to create a hostile environment.

Title VII protections were strengthened with the Civil Rights Act of 1991. Women were given the right to sue for compensatory and punitive damages for sexual harassment. An 
important provision of the Civil Rights Act of 1991 is it allows harassment and discrimination plaintiffs the right to a jury trial in federal court.

Two important cases and rulings occurred in 1991. In Ellison v. Brady, the reasonable person standard gave in to the "reasonable woman standard." Sexual harassment cases were to be examined not from the perspective of the defendant but the plaintiff. The second case, Jenson v. Eveleth Taconite Co. was the first sexual harassment class action case. The Jenson ruling expanded damages to include psychological injuries that were to be included in awards. Employers were to be held accountable and liable in the two 1998 court rulings in Faragher v. City of Boca Raton, Florida and Burlington v. Ellerth. The same year, same sex harassment was addressed in Oncale v. Sundowner Offshore Services. The court wrote, "Any discrimination based on sex is actionable so long as it places the victim in an objectively disadvantageous working condition, regardless of the gender of either the victim, or the harasser."

In 1994, the "Violence Against Women Act of 1994 was passed. This law limits acceptability of evidence of the plaintiff's past sexual history in sexual harassment cases and allows such evidence against accused sexual harassers. Congress passed the Government Accountability Act in 1995. Congress's own members are subject to the same employment laws as the rest of the country.

Retaliation was addressed in 2005 and 2006. In 2005, the Supreme Court ruled in Jackson v. Birmingham Board of Education that punishing someone for reporting sexual harassment and sex discrimination was illegal according to Title IX. Retaliation was defined as any adverse employment decision that would dissuade a reasonable worker from making a charge of discrimination. In Reeves v. C.H. Robinson Worldwide, Inc. in 2010, a hostile work environment was defined as a workplace where sexually explicit language and pornography are present and may exist based on treatment not only at a targeted employee but as a group. In 2013, the Reauthorization of the "Violence Against Women Act" was expanded to Native American tribal lands. Victims on reservations become protected. This act also extended coverage to gay individuals and immigrants.

Congress passed and the President signed the Tax Reform Act of 2017. This law made changes in the tax law covering workplace sexual harassment. Under the law businesses could no longer deduct settlement payments or attorney's fees for sexual harassment charges if the settlement or payment was subject to a nondisclosure agreement.

\section{RECENT SEXUAL HARASSMENT EXAMPLES}

\section{Ashley Alford vs. Aaron Rents (2011)}

On September 30, 2008, The U.S. Equal Employment Opportunity Commission (EEOC) filed an egregious sexual harassment case (Case No. 3:08-cv-00683-MJR-DGW), for Ashley Alfred against Aaron Rents, Inc. The EEOC alleged Richard Moore, the general manager of the Fairview Heights, Illinois store made sexually explicit comments, unwanted physical contact, sexual assault and requests for sex on a regular basis to Ashley Alford. The complaint alleged that a manager, "...touched Alford's body in a sexually offensive manner on a number of occasions and he exposed himself to her several times. Alford complained to her direct supervisor and called the company hotline, but no action was taken to end the harassment. In October 2006, [the manager] sexually assaulted Alford in the Fairview Heights facility." Alfred alleged that Moore attacked her, yanked up her shirt and then masturbated, ejaculating on her. The jury verdict was $\$ 95$ million award to Alfred. The jury verdict was later reduced to $\$ 41.3$ million because of a cap on federal damages. Aaron Rents moved to either reconsider the verdict or order a new trial. Court records show attorneys in the case subsequently reached an out-of-court settlement.

\section{Ani Chopourian v. Catholic Healthcare West (2012)}

On February 28, 2012, a federal jury in California awarded Ani Chopourian \$168 million (U.S. District Court, Eastern District, Sacramento/ 2:09-CV-02972-KJM-KJN), likely the largest judgment in U.S. history for a single victim of workplace sexual harassment. Chopourian worked as a Cardiac Surgery 
Physician Assistant for Mercy General and Mercy San Juan Hospitals in Sacramento. During her employment and on a daily basis, Chopourian alleged she endured sexually inappropriate behavior on a daily basis in and out of the operative rooms. Surgeons and other coworkers made repeated unwelcome and sexual advances and propositions including vulgarity and buttocks slapping frequently in present of and sometimes involving managers of the department. Chopourian filed multiple complaints to no avail.

\section{Gretchen Carlson v. Roger Ailes (2016)}

A former Fox News Anchor, Gretchen Carlson, agreed to settle a sexual harassment lawsuit she filed against former FOX News CEO Roger Ailes for \$20 million. Carlson alleged she was a victim of sexual harassment and retaliation. Carlson received one of the largest settlements in sexual harassment cases and is likely for Fox's eagerness to do damage control. "Fox must have evaluated the evidence and made the economic decision that going to trial would reveal unflattering and distasteful behavior and prolonged negative discussion.

\section{THE TAX REFORM ACT OF 2017 IMPLICATIONS FOR SEXUAL HARASSMENT IN THE WORKPLACE}

The Equal Employment Commission reports the number of sexual harassment charges filed with the commission on yearly basis. In 2010, the EEOC reported 7,944 charges. Since 2010, the number of charges filed with the Commission has declined and by 2017 the number had fallen to 6,696. Even though the number of charges has declined, there are still thousands of charges each year. In recent years, sexual harassment has received much renewed attention and publicity. A movement called "Me Too" was started to advocate for those that were sexually harassed and to bring attention internationally to the wide spread abuse. In 2017, Congress acted to address the secretiveness of the controversial issue by making it costly for corporations to hide the charges and settlements. The Tax Reform Act of 2017 changed the law covering sexual harassment by disallowing businesses to deduct settlement payments and attorney's fees for sexual harassment claims if the settlement or payment was subject to a nondisclosure agreement. The likely intention of this change is to make sexual harassment claims more transparent and settlement specifics available to the public. This tax change presents a set of important decisions that a business must address if it has a valid or even invalid sexual harassment charge. A specific framework to evaluate the choices and results should be defined. The business should of course, address this charge and act to prevent future charges. A proactive plan including training, instituting an ethics program and having strong discipline enforcement will be beneficial. However, the business is facing a possible threat to its future performance and must minimize the economic damages. A methodology to properly evaluate their best pathway could be a capital budgeting analysis. The business must first decide if it is better to defend itself in court or settle out of court with the accuser. Through discovery and depositions, the business will know specifics and evidence and can estimate the cost for each alternative. A settlement allows the business a known result with a fairly accurate estimate of cost. If the business decides to have its day in court, the trier of fact findings and award are unknown until verdict. Going to trial, a business has tremendous risk exposure to a possible extremely large judgement. If the business decides its best alternative is to settle the matter, a decision on implementing a nondisclosure agreement (NDA) is required.

\section{THE PROPER METHODOLOGY TO CONSIDER THE NONDISCLOSURE DECISION}

The scientific approach to address the decision for the desirability to execute a NDA is to structure the analysis in a capital budgeting or cost-benefit methodology. The decision methodology should be structured as a SWOT matrix. In the matrix, the advantages and disadvantages of the decision and expected cash flow costs are identified, and the analysis is then performed in a capital budgeting framework. 
The economic decision facing the business relates to the cost of using or not executing an NDA? Such a decision involves making one of the two choices, which can be modeled using a dummy dependent variable model, such as, logit, probit, or tobit model with direct and indirect costs associated with the NDA or a non-NDA choice as independent variables. The direct costs of executing a NDA are the attorney fees and more importantly the loss of the tax deduction. The business will not be allowed to expense for tax purposes the sexual harassment settlement as well as the legal costs for addressing the charge. Settlements involving expensive litigation work and large payments will have a large non-taxdeductible opportunity cost. For example, if the probable legal fees are $\$ 4$ million and the matter can most likely be settled for $\$ 10$ million, the loss of the tax deduction at a 21 percent tax rate is $\$ 2.94$ million. However, allowing the settlement to continue to be news, promotes additional attention to the matter. If a NDA is not executed, the party may discuss the sexual harassment charges, settlement and the business's deficiency. Additional public media may continue damaging the business's reputation, impacting future sales and triggering the business to spend additional money to overcome the adversity. Instituting a NDA normally bars the injured party from further discussing the matter. The company can take some comfort in knowing the party is not going to appear on radio and television or social media to discuss the matter or will not write a book. An advantage of requiring a NDA is it will allow secrecy of the terms and payment. There will not be a press release stating the final settlement or the live appearance of the plaintiff discussing the matter.

Businesses desire the bad publicity to end as quickly as possible. Research has shown that bad publicity has an adverse impact on recruiting employees. A study by CareerBuilder found that 71 percent of U.S. workers would not apply to work at a company with negative press (Kasperkevic 2017). Also, negative publicity has an impact on potential and existing customers and the business' stock price. Investigations have found that 80 percent of people report they will not purchase from a business that has negative reviews (Smith and Anderson, 2016). United Airlines stock fell by over 10 percent costing its shareholders approximately 180 million after a known musician whose guitar was damaged recorded a song titled, "United Breaks Guitars." (Sickler, 2017).

There are advantages to forgoing an NDA. In many instances, the business should not enter into a NDA. Requiring and executing an NDA may make bring additional unwanted attention to the matter. The media and the public may think what does the business want to hide and what other unsavory actions has the business been involved in? If there is a high news cycle at the time, the settlement may not be covered by the media or given insignificant attention or time. If the accuser is not very credible, has a questionable reputation or has significant publicity issues, the need for an NDA will be less. Additionally, if the settlement shows that the business has and will take corrective action that will resolve all issues, not executing an NDA may be positive (Bednar, Boivie and Orince, 2013). If the business's reputation has already been significantly tarnished with the negative publicity prior to the settlement, likely a large sum of money will have to be spent for damage control regardless of the NDA. If the information on the settlement is made public and a public appearance of the accuser will result in the business only having to have marginal increase in positive advertising, then there is little advantage of the NDA. The informed accuser will know that the business is willing to forgo a significant tax deduction if the business demands an NDA. The accuser will recognize the business believes additional exposure would be damaging and are willing to pay for closure. Knowledge of a business desiring a NDA places the accuser in a stronger negotiating position to require a larger settlement. Placing accusers in a stronger negotiating position is most likely a non-intended consequence of the Tax Reform Act of 2017.

\section{CONCLUSION}

The Tax Reform Act of 2017 has changed how business should address workplace sexual harassment charges. The law does not allow businesses to deduct the legal fees or the settlement payments if a nondisclosure agreement (NDA) is used. Businesses must act in their best economic interest and make the NDA decision based on minimizing total costs associated with sexual harassment charge. This provision 
has significant economic implications. The Corporation must decide if preventing the party from publicly discussing the matter and settlement is worth the cost of losing the deduction. The scientific approach to address the decision for the desirability of executing an NDA is two pronged. On one hand, such a choice can be analyzed in a capital budgeting or cost-benefit methodology. The decision methodology should be structured as a SWOT matrix. In the matrix, the advantages and disadvantages of the decision and expected cash flow costs are identified, and the analysis is then performed in a capital budgeting framework. On the other hand, the economic decision facing the business relates to a binary choice of using or not executing a NDA? Such a decision involves making one of the two choices, which can be modeled using a dichotomous decision function, such as, logit, probit, or tobit model with direct and indirect costs associated with the NDA or a non-NDA choice as independent variables. The most theoretically correct method would be to address the decision using a capital budgeting framework. Direct costs for executing or not executing the NDA will be fairly easy to estimate. Long-term costs resulting from bad publicity for executing or not executing will be more complex but attainable. Of course, the business must take immediate action to change the environment that allowed the unacceptable behavior to occur and ensure safe guards are permanently in place.

Should the NDA decision be considered an ethics issue for the business? Is it more ethical to allow the abused party to speak freely of the settlement? Or, is a very fair settlement that makes the injured party whole and provides significantly extra money to compensate for the injustice sufficient to justify a NDA and allow the business to move on? Is a very large cash settlement sufficient to expect the aggrieved party to end all conversations?

\section{ENDNOTE}

1. SEC. 13307. DENIAL OF DEDUCTION FOR SETTLEMENTS SUBJECT TO NONDISCLOSURE AGREEMENTS PAID IN CONNECTION WITH SEXUAL HARASSMENT OR SEXUAL ABUSE. (a) DENIAL OF DEDUCTION.-Section 162 is amended by redesignating subsection (q) as subsection (r) and by inserting after subsection (p) the following new subsection: " $(q)$ PAYMENTS RELATED TO SEXUAL HARASSMENT AND SEXUAL ABUSE.-No deduction shall be allowed under this chapter for- "(1) any settlement or payment related to sexual harassment or sexual abuse if such settlement or payment is subject to a nondisclosure agreement, or "(2) attorney's fees related to such a settlement or payment.". (b) EFFECTIVE DATE.- -The amendments made by this section shall apply to amounts paid or incurred after the date of the enactment of this Act. 


\section{REFERENCES}

Ashley Alford v. Aaron Rents, Inc. D/B/A Aaron Sales and Lease Ownership, et al. 3:08-cv-683 ct U.S. (2011).

Barnes v. Costle, 516 F.2d 983 (D.C. Cir. 1977).

Barnes v. Train, 13 Fair Empl. Prac. Cas. (BNA) 123 (D.D.C. 1974).

Bednar, M., Boivie, S., \& Prince, N. (2013). Bur Under the Saddle: How Media Coverage Influences Stategic Change. Organization Science, 24(3).

Burlington Industries, Inc. v. Ellerth, 524 U.S. 742, 751. (1998).

Campbell. J. (2016, February 5). The First Brave Woman Who Alleged Sexual Harassment.

Charges Alleging Sex-Based Harassment (Charges filed with EEOC) FY 2010 - FY 2016. (2016). Equal Employment Opportunity Commission.

Chopourian v. Catholic Healthcare West. Mercy General Hospital 2:09-CV-02972-KJM-KJN. U.S 2012.

Conte, A. (2010). Sexual Harassment in the Workplace (4 ed.). Wolters Kluwer, pp. 3-278.

Ellison v. Brady, 924 F. 2d 872 - Court of Appeals, 9th Circuit 1991.

Jackson v. Birmingham Board of Education, 544 U.S. 167. (2005).

Larson, A. (2017, January 10). Sexual Harassment Law. ExpertLaw.

MacKinnon, C.A., \& Siegel, Reva I. (2004). Directions in Sexual Harassment Law. Yale University. p. 8. Marketplace "for companies, bad reputations come at a cost Jana Kasperkevic. (2017, July 21). Sexual Harassment. EEOC. U.S. Equal Opportunity Commission.

McElroy, W. (2004, October 27). The Sad Evolution of Sexual Harassment. Retrieved August 15, 2017. Meritor Sav. Bank, FSB v. Vinson, 477 U.S. 57, 65 (1986).

Oncale v. Sundowner Offshore Serv., Inc., 523 U.S. 75, 81 (1998).

Reeves v. CH Robinson Worldwide, Inc., 569 F. 3d 1290 - Court of Appeals, 11th Circuit, 2009.

Sickler, J. (2017, November 25). Reputation Management.com Why a Great Company reputation is Important.

Smith, A., \& Anderson, M. (2016, December 19). Online Reviews” Online Shopping and E-Commerce”. Pew Research Center.

Williams v. Saxbe, 413 F. Supp. 654 (D.D.C. 1976). 